\title{
Klasszikus és alkalmazott matematikai ismeretek a középiskolában
}

\section{Classical and applied mathematics in secondary school}

\author{
CS. KÉZI \\ University of Debrecen, kezicsaba@science.unideb.hu
}

Absztrakt. Egy középiskola két különböző, de hasonló képességekkel rendelkező osztályban írattam egy-egy tesztet. Az egyik osztályban alkalmazott matematikai feladatokat, a másik osztályban tisztán matematikai szövegezésú feladatokat kellett megoldani a tanulóknak. Megvizsgáltam, hogy a két feladatsor átlagos pontszáma között volt-e szignifikáns eltérés.

Abstract. In a secondary school I wrote a test with similar abilites student. In one class students had to solved applied mathematics exercises, in other class there were pure mathematics exercises. I anayzed the results.

\section{Bevezetés}

A mátészalkai Esze Tamás Gimnáziumban a 12. évfolyam két osztályában egy-egy feladatsort írattam meg. Az egyik teszt alkalmazott matematikai feladatokat tartalmazott, ahol először fel Kellett írni a matematikai modellt, majd azután megoldani a matematikai feladatot. A másik teszt az ezen modellből származó „tisztán” matematikai megfogalmazású feladatokat tartalmazta.

Mindkét feladatsor négy feladatot tartalmazott. A tanulók mindkét osztályban hasonló képességűek voltak. A matematika tanáruk is ugyanaz, így a tananyagban egyformán haladnak, azonos matematikai előképzettséggel rendelkeznek.

A tanulók a feladatok megoldásához függvénytáblázatot és számológépet használhattak, ezen kívül más megengdett segédeszközük nem volt.

\section{Az alkalmazott matematikai feladatokat tartalmazó teszt}

Az alkalmazott matematikai feladatokat tartalmazó teszt az alábbi négy feladatot tartalmazta:

1. feladat:

Egy hegy aljáról a tetejére libegővel és gyalog egyaránt fel lehet jutni. Ha az ösvényen megyünk a hegy tetejére, közvetlenül a libegő állomásához jutunk.

A libegő pályájának meredeksége $13^{\circ}$, a hegy oldalán felvezető egyenes ösvényé $15^{\circ}$. A libegő indulási pontjától 150 métert kell síkterepen előre sétálnunk, hogy elérkezzünk az ösvényig. 
Mennyi a kötélpálya hossza és mennyi az ösvény hossza?

2. feladat:

Egy sebességmérő radar az autóút egyenes szakaszán 30 méter távolságban érzékelt egy balról közeledő autót. Egy másodperc múlva ugyanazt az autót már jobbra, 40 méterre mérte be.

$\mathrm{Az}$ autó első helyzete (A), a radar (R) és az autó második helyzete (B) által meghatározott ARB 4 nagysága $30^{\circ}$.

3. feladat:

Egy parkban öt egyforma, csonkakúp alakú virágágyat készítenek. Az alapkör sugara 5 méter, a fedőlap sugara 4,6 méter, a magasság 50 centiméter. Hány köbméter föld kell hozzá?

4. feladat:

Egy anyagi pont egy erő hatására az

$$
x^{2}+y^{2}-4 x+6 y=12
$$

egyenletű körön mozog. Amikor az anyagi pont a $\mathrm{P}=(5 ; 1)$ pontba érkezik, akkor az erő hatása megszűnik. Írjuk fel az anyagi pont további pályájának egyenletét! (Segítség: az erő hatásának megszűnése után az érintőegyenes irányában halad tovább a pont.)

\section{A „tisztán” matematikai feladatokat tartalmazó teszt}

A „tisztán” matematikai feladatokat tartalmazó teszt az alábbi négy feladatot tartalmazta:

1. feladat:

Az ABC háromszög A csúcsánál lévő szöge $13^{\circ}$. A C csúcsból induló egyenes a háromszög $\mathrm{AB}$ oldalát a $\mathrm{D}$ pontban metszi. A CDBŁ nagysága $15^{\circ}$. Az AD szakasz hossza 150 méter. Mekkora az AC és a DC oldalak hosszúsága?

2. feladat:

Egy háromszög két oldalának hossza 30 méter és 40 méter. A két oldal által bezárt szög nagysága $30^{\circ}$. Mekkora a háromszög harmadik oldala?

3. feladat:

Egy csonkakúp alapkörének sugara 5 méter, a fedőlap sugara 4,6 méter. a magassága 50 centiméter. Mekkora a térfogata?

4. feladat:

Egy kör egyenlete $x^{2}+y^{2}-4 x+6 y=12$. Írjuk fel a kör $P=(5 ; 1)$ pontjába húzott érintőegyenesének az egyenletét! 


\section{A teszteredmények elemzése}

Az alábbi táblázat mutatja az egyes feladatokra kapott pontszámokat az alkalmazott matematikai feladatokat tartalmazó teszt esetén:

\begin{tabular}{|c|c|c|c|}
\hline & 2 pont & 1 pont & 0 pont \\
\hline 1. feladat & 14 & 3 & 12 \\
\hline 2. feladat & 13 & 5 & 7 \\
\hline 3. feladat & 9 & 4 & 12 \\
\hline 4. feladat & 14 & 3 & 8 \\
\hline
\end{tabular}

1. táblázat

$\mathrm{Az}$ átlagos pontszám az első feladatra 1,24, a második feladatra 1,24, a harmadik feladatra 1, a negyedik feladatra szintén 1 .

Az alábbi táblázat mutatja az egyes feladatokra kapott pontszámokat a „tisztán” matematikai feladatokat tartalmazó teszt esetén:

\begin{tabular}{|c|c|c|c|}
\hline & 2 pont & 1 pont & 0 pont \\
\hline 1. feladat & 8 & 5 & 12 \\
\hline 2. feladat & 6 & 5 & 14 \\
\hline 3. feladat & 7 & 2 & 16 \\
\hline 4. feladat & 7 & 5 & 13 \\
\hline
\end{tabular}

2. táblázat

Az átlagos pontszám az első feladatra 0,84, a második feladatra 0,68, a harmadik feladatra 0,64, a negyedik feladatra 0,76 .

Ellenőrizhető t-próbával, hogy minden feladat esetében az átlagos pontszámok között szignifikáns eltérés mutatkozik. Például az első feladat esetében a t-statisztika számolt értéke 3,46, míg 95\%-os biztonsági szint mellett a 24-es szabadsági fokhoz tartozó táblázati érték 2,06, így a számolt érték lényegesen nagyobb, mint a táblázatbeli érték, ami azt jelenti, hogy az első feladatot lényegesen jobban oldotta meg az a társaság, akik nem a „tiszta” matematikai szöveget kapták meg.

Hasonló eredményt kapunk a többi feladat pontszámainak vizsgálatakor is.

\section{Összefoglalás}

Jelen cikkben azt vizsgáltam, hogy van-e szignifikáns eltérés a középiskolai tanulók teljesítményében, ha „tisztán” matematikai feladatokat oldanak meg, vagy ha valamilyen hétköznapi életből vett példát. Vizsgálatom eredménye az lett, hogy igen, van. Lényegesen motiváltabbak és jobban koncentrálnak, ha olyan feladatokat kell megoldaniuk, ahol látják azt, hogy „miért számolnak”, mintha cask egy „matematikai” feladatot kell megoldaniuk. 
International Journal of Engineering and Management Sciences (IJEMS) Vol. 4. (2019). No. 4

DOI: 10.21791/IJEMS.2019.4.46.

Bár az alkalmazott matematikai modell felállítása plusz feladatot jelent a „tisztán” matematikai feladatokhoz képest, mégis a tanulók szívesebben és nagyobb odaadással foglalkoznak ilyen jellegű feladatok megoldásával.

\section{Hivatkozások}

[1] www.kooperativ.hu/matematika.

[2] Czapáry E., Czapáry E., Csete L., Hegyi Gy., Iványiné Harró Á., Morvai É., Reiman I., Matematika gyakorló és érettségire felkészítő feladatgyájtemény, Nemzeti Tankönyvkiadó, 2013. 